\title{
APPLYING RANSAC ALGORITHM FOR FITTING SCANNING STRIPS FROM AIRBORNE LASER SCANNING
}

\author{
Wioleta BŁASZCZAK-BAK ${ }^{1}$, Joanna JANICKA ${ }^{1}$, \\ Anna SOBIERAJ-ŻŁOBIŃSKA ${ }^{2}$ \\ ${ }^{1}$ University of Warmia and Mazury in Olsztyn, Poland \\ ${ }^{2}$ Gdansk University of Technology, Gdańsk, Poland
}

\begin{abstract}
During the development of the data acquired by airborne laser scanning the important issue is the fitting and georeferencing of ALS point clouds by means of the tie surfaces and the reference planes. The process of scanning strips adjustment is based on mutual integration of point clouds (scanning strips) and their adaptation to the reference planes. In simultaneous adjustment all strips are combined into one geometrically coherent block, to which the coordinates are given. In the process of determining discrepancies between scanning strips it is important to determine the correct size of the shifts (offsets). Authors propose to do this by using RANSAC algorithm.
\end{abstract}

Keywords: airborne laser scanning, RANSAC algorithm, fitting.

\section{INTRODUCTION}

One of the LIDAR technology (Light Detection And Ranging) is an airborne laser scanning (ALS Airborne Laser Scanning), which allows for efficient acquisition of data about the area. The result of the scanning is a collection of spatial coordinates of points called a point cloud. The advantages of ALS is relatively short data acquisition time compared to the classical methods and the ability to perform measurements at different weather conditions. On the one

${ }^{1}$ Corresponding author: University of Warmia and Mazury in Olsztyn, Institute of Geodesy, M. Oczapowskiego 2 st, 10-719 Olsztyn, Poland

${ }^{2}$ Corresponding author: Gdansk University of Technology, Department of Geodesy, Narutowicza 11/12 st, 80-233 Gdansk, Poland 
hand, obtaining such data sets allows to perform a series of analyzes. On the other hand, it can be a problem during development of such big sets. Therefore, since the ALS technology has become one of the methods of obtaining spatial data, many different algorithms for the development of such data are used and new ones are still created [4], [8].

In the processing of raw data from airborne laser scanning the important task is the identification of points belonging to the relevant groups of objects. The above process is carried out by classification and filtering the point cloud. Filtration is a process in which the two groups of points are obtained: points representing terrain and points representing the situational details [2], [3]. The classification is based on the division of the point cloud on the separate groups, their number depends on the aim of adopted classification. The characteristics of each group is related to the type of surface from which the laser light is reflected, so the following groups can be distinguished: terrain, vegetation, buildings, etc. [1].

Classification and filtration are certain stages that are repeated during the development of point clouds. Another issue is the adjustment of ALS point clouds. Due to the fact, that the data are collected during the flight point clouds are in the form of the scanning strips with mutual coverage. These strips are then combined into one larger set - LiDAR block. The adjustment of ALS scanning strips is based on mutual integration of point clouds and their adaptation to the reference planes. Fig. 1 shows the idea of block adjustment of scanning strips on the basis of mutual belt coverage and reference planes.

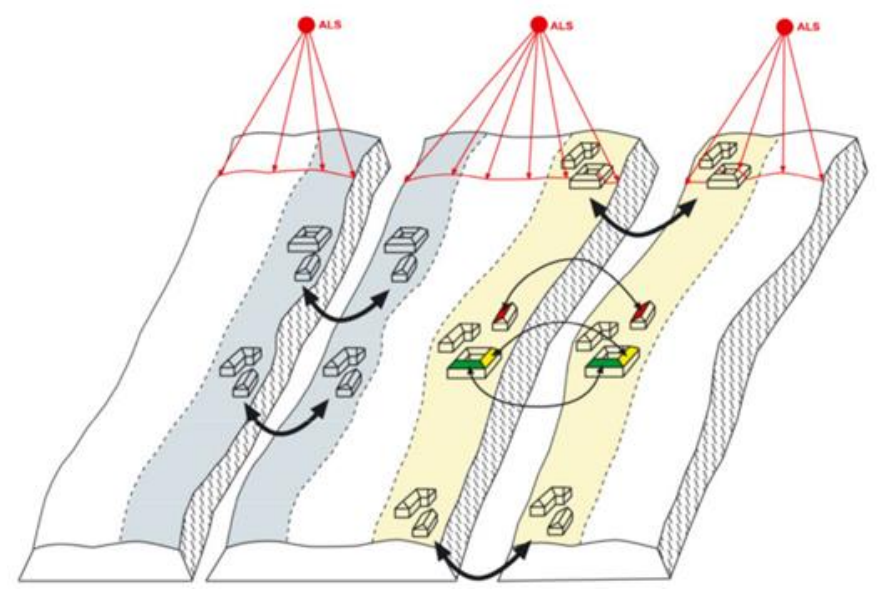

Fig. 1. The idea of block adjustment of ALS scanning strips (source: [12]) 
The block adjustment of scanning strips is conducted in stages presented in Fig.2.

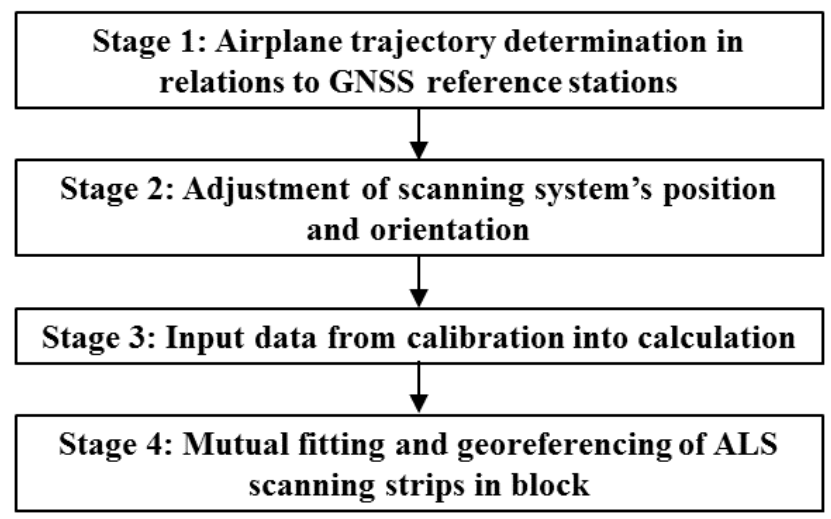

Fig. 2. Process of block adjustment of ALS scanning strips (source: own work on the basis of [12])

During the adjustment of the ALS scanning strips, inter alia, the position and orientation of the scanning system is calculated and the determination of exterior orientation of the camera is conducted as well. An important step is stage 4, where the mutual fitting of ALS scanning strips is made. For this purpose, various methods of point cloud adjustment are used. In the literature dealing with the subject of the ALS data development there is a lot of space devoted to the adjustment of point clouds. It can be divided as follows:

1. Early methods of ALS data adjustment

- Kilian's method: the procedure consists of two steps: (1) tie and control points are calculated (2), then this information is used to connect the individual scanning strips and to transform the entire block to an external coordinate system [10], [7].

- Crombaghasa's method: fitting of scanning strips is conducted by estimating and removing the vertical differences in the coverage areas, as well as differences in height measured by laser and by during external measurement known as the reference. The values of discrepancies between the strips act as tie points, while the reference measurement - as the control points [5].

2. Adjustment methods based on the 3D transformation

- Vosselamn and Mass's method: adjustment includes compensation for horizontal differences because in authors' opinion planimetric systematic errors are often much more important than LiDAR vertical errors [16].

- Vosselman's method of extracting linear elements: linear elements, such as roof edges, ridges, ditches are used to determine the scope of the 
discrepancies between scanning strips. Correct estimation of shifts (offsets) requires the application of appropriate geometric model which allows for modeling linear elements. The measurement of the gap between the scanning strips can be based on the extraction of ridge roof shape or on extracting the ditch's shape [15].

The use of linear objects such as eg. ditches, ridges of roofs, parts of the road may have considerable importance especially in the development of cloud points concerning rural areas. In these areas, linear elements, even minor, may be the only ones that can be used to determine the horizontal offset between the scanning strips. One of the described methods is fitting cosine curve in a point cloud representing the road. Any function allowing for modeling linear element can also be used.

The authors propose to determine a shift between scanning strips using two sets of points representing the road. The sets of points are derived from two ALS scanning strips. To determine the offset authors used the RANSAC method [11] with function describing the plane. The aim of the work is fitting plane into a point cloud representing the road, by applying the RANSAC method.

\section{RANSAC ALGORITHM}

The RANSAC method was developed to estimate the parameters of the model based on a data set containing a large number of outliers [11]. Initially it was used mainly for computer vision, allowing to identify objects even when the data set contains many outliers. RANSAC belongs to a group of numerical methods, it is an iterative fitting of the model to the data set having a number of observations. The advantage of this method is the possibility of using it in a situation when the data set consists of a large number of outliers. Most estimation methods belonging to the gross error resistant group allow to detect this type of observation to a certain level of their occurrence. If it is above 40$50 \%$, these methods do not provide the desired results. The advantage of RANSAC method is that correct results can be obtained even in case when the contents of outliers is above $50 \%$ of the entire data set [9], [14].

The number of iterations is determined by the following formula:

$$
T_{i t e r}=\frac{\log \varepsilon}{\log (1-\mathrm{q})}
$$

where:

$\varepsilon$ - the probability of the model misidentification,

q - parameter calculated by the following equation: 


$$
q=\left(\frac{N_{i}}{N}\right)^{k}
$$

wherein:

$\mathrm{N}_{\mathrm{i}}$ - points that belong to a identified set,

$\mathrm{N}$ - total number of points in the input data set,

$\mathrm{k}$ - the minimum number of data which are necessary to unambiguously determine the model.

Additional information, which are used in the process of fitting the model are: minimum number of observations required to model estimation, minimum number of iterations, tolerance range, in which there are valid data (ie. inliers) and volume of set, which allows the completion of the iteration.

The RANSAC algorithm consists of the following steps:

1. Determining the type of model.

2. Selection of the minimum number of points required to determine the parameters of the model.

3. Random selection of model parameters.

4. Determination of the tolerance range.

5. Determining the minimum amount of data, which is to meet the tolerance range, to create a final model.

6. Identify how many points from all of the analyzed set fits into the model with the assumed tolerance (inliers set).

7. If it turns out that the number of data from the inliers set is insufficient and exceeds a defined threshold, the model parameters are determined again using all identified inliers.

8. Repeat steps 3-8 in $\mathrm{N}$ iterations (the maximum number of iterations is determined by the user).

Fig. 3 shows an example of a simple fitting of a line into a set of points; many of them are outliers. Fig. 3a shows the entire data set, and Fig. 3b shows a straight line fitted to the correct observation excluding the outliers.

In this study the RANSAC method with function of a plane was tested. In the case of fitting the plane into the data set, the minimum number of points needed to estimate such model is 3 . The minimum number of iterations is calculated according to formula (2.1). File size and the tolerance range, which contains the correct data (inliers) are selected for a particular task.

Algorithm is based on an iterative repetition of two stages: hypothesis and tests. Stage of hypothesis is associated with the concept of a minimum set (the minimal sample set). It is the smallest number of points that are needed to calculate the model parameters. The minimum number is determined by the selected function describing the model. In the case of extraction of plane the set will require a minimum of three points. On the basis of randomly selected 
observation the starting model (hypothetical) is estimated. All other data are tested for fitting the hypothetical model. If any or all of the selected points are outliers, then a hypothetical model does not fit with the rest of the data. Therefore, the algorithm will skip this model and the next set of three points for a different hypothetical model will be randomly selected. In testing step it is checked iteratively whether the observations of the entire data set are consistent with the hypothetical model.

a)

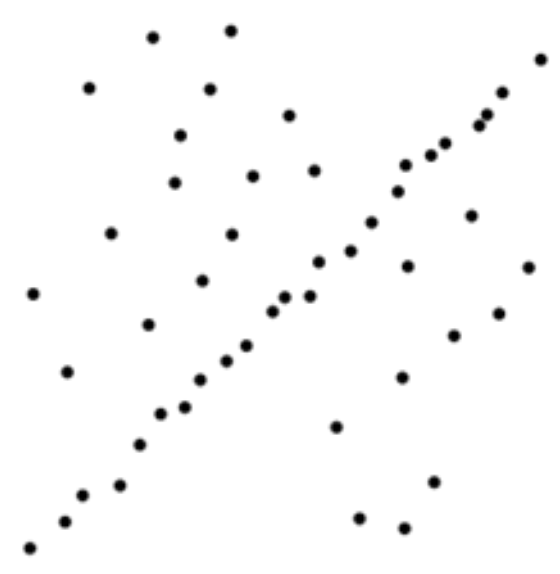

b)

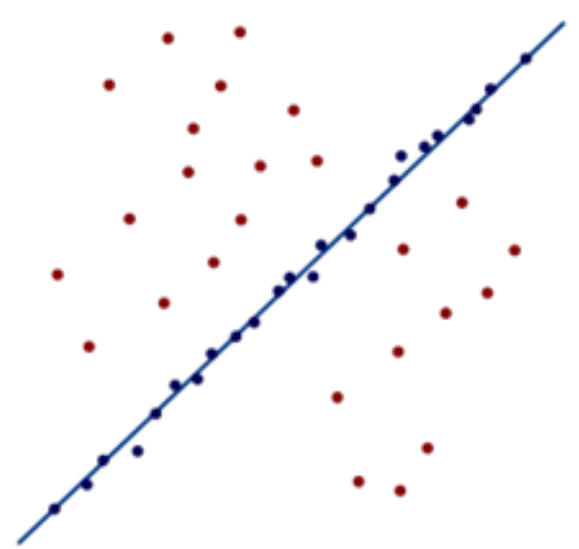

Fig. 3. a) The set of points with outliers,

b) Simple fitting of line using RANSAC (source: [9])

The estimated model is correct, if it has a sufficient number of points that have been classified as a set of valid observations (inliers). Best collection of observation, which is selected from the entire data set is called a set of consensus (Consensus Set).

\section{THE RESEARCH OBJECT}

The research object was a fragment of a point cloud covering the street Sielska in Olsztyn (Poland). The study area is indicated in Fig. 4. Airborne laser scanning was made by Visimind Ltd. In tests a fragment of the results of the measurement (scanning strips with double coverage) was used. Scanning angle was 60 degrees, with a scan rate of $10,000 \mathrm{~Hz}$. Scanning was performed during the helicopter flight with speed of $50 \mathrm{~km} / \mathrm{h}$ at a height of $70 \mathrm{~m}$. 


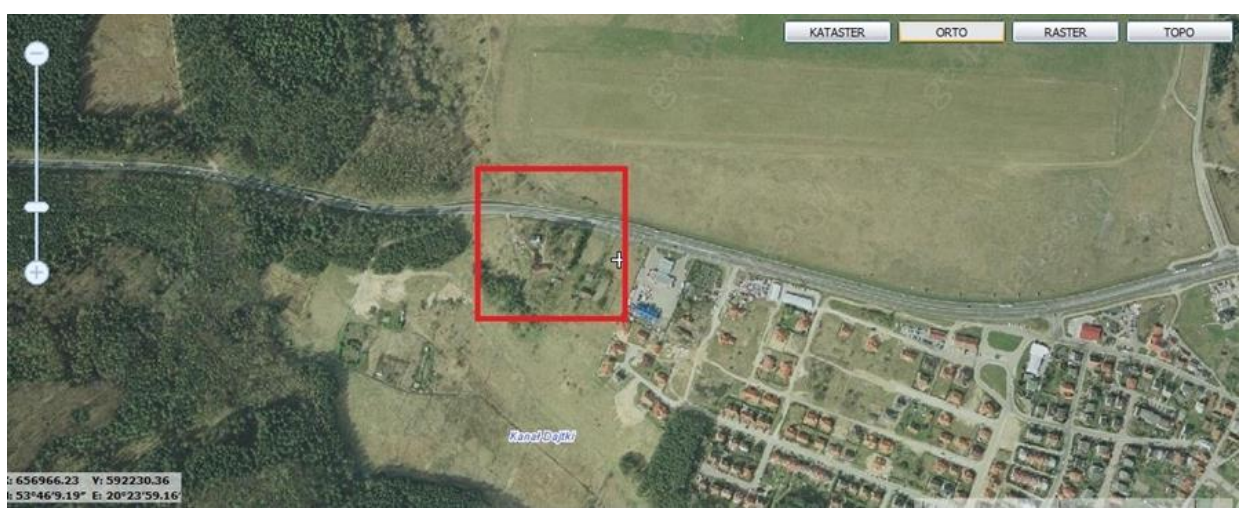

Fig. 4. Map of the Olsztyn with a fragment of the analyzed area (source: www.geoportal.gov.pl)

A fragment of the original ALS data set, which was used as an object of research work is presented in Fig. 5. Presented fragment comes from a scanning strip no. 1.

a)

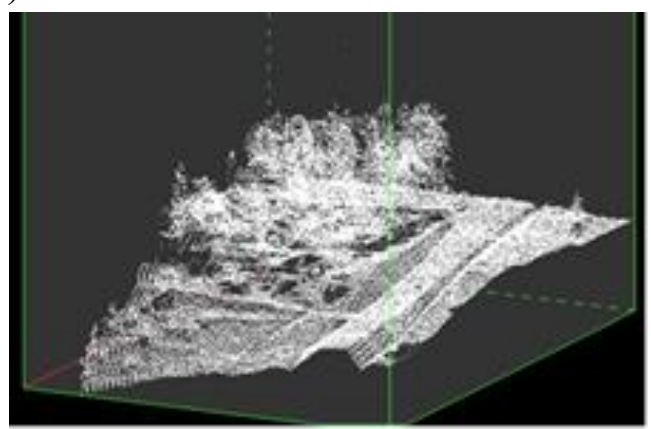

b)

Fig. 5. The fragment of the original ALS point cloud, a) perspective view, b) top view(source: own work developed in DTMaster v.5.4)

In this work it was decided that fitting of the scanning strips will be conducted by means of data covering a lane (road and ditches) visible on measured area, located in dual coverage (the result of the ALS measurement). In order to accurately extract the set of points showing the lane, the filtration was carried out first. The algorithm of hierarchical linear prediction (Pfeifer et al. 2001) built-in program DTMaster (Demo v.5.4) was used for this purpose. Cloud point after filtration is shown in Fig. 6. 


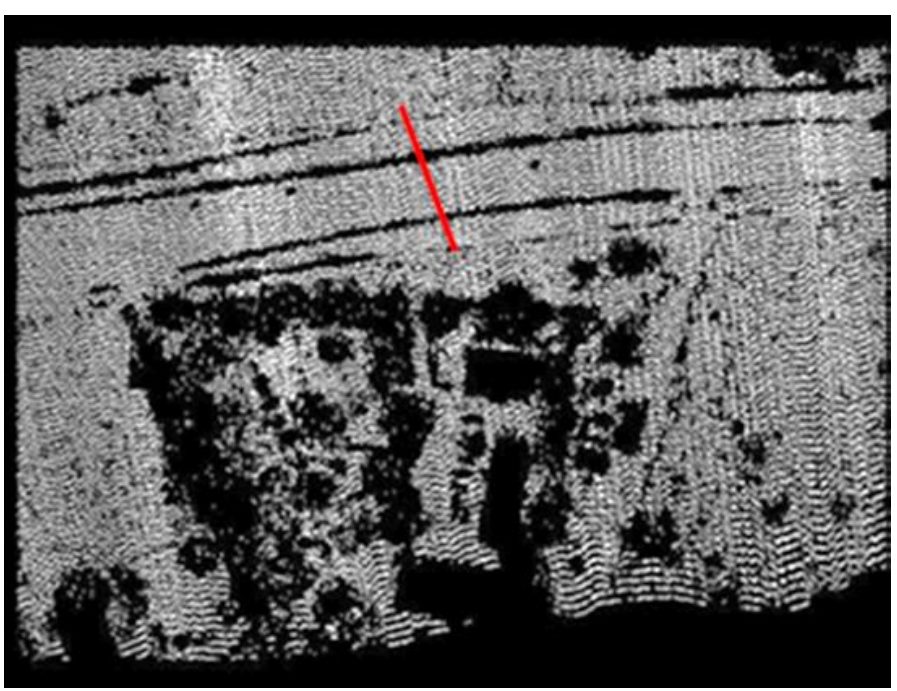

Fig. 6. The fragment of ALS point cloud after filtration, the top view (source: own work developed in DTMaster v.5.4)

In Fig. 6 a line defining the cross section is indicated. Lane's "cut" is of width of $50 \mathrm{~cm}$ and it also the way how two sets of points from double coverage representing the lane are selected. These sets are presented in Fig. 7.

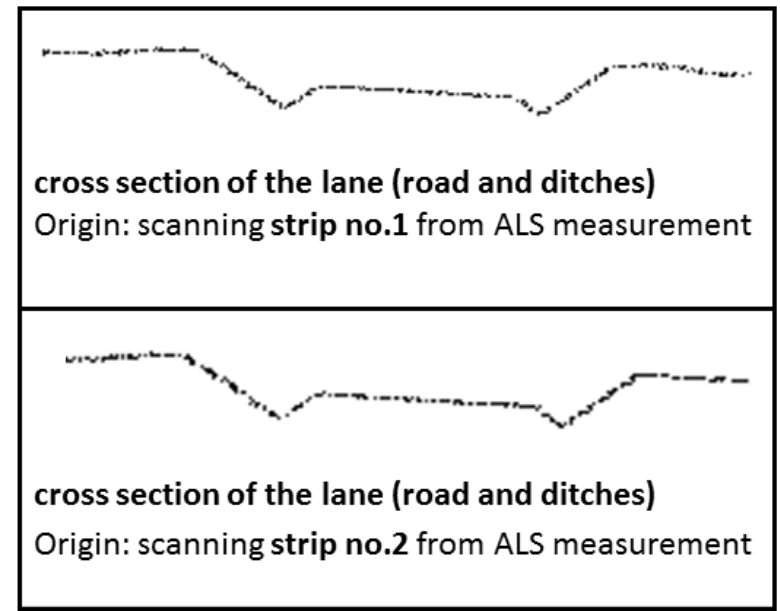

Fig. 7. The sets of points showing a lane, a cross section of the roadway (source: own work)

The extracted fragments of point clouds of two ALS scanning strips were then integrated by means of RANSAC method. 


\section{TESTS}

In order to confirm the effectiveness of the proposed solution the numerical tests were performed.

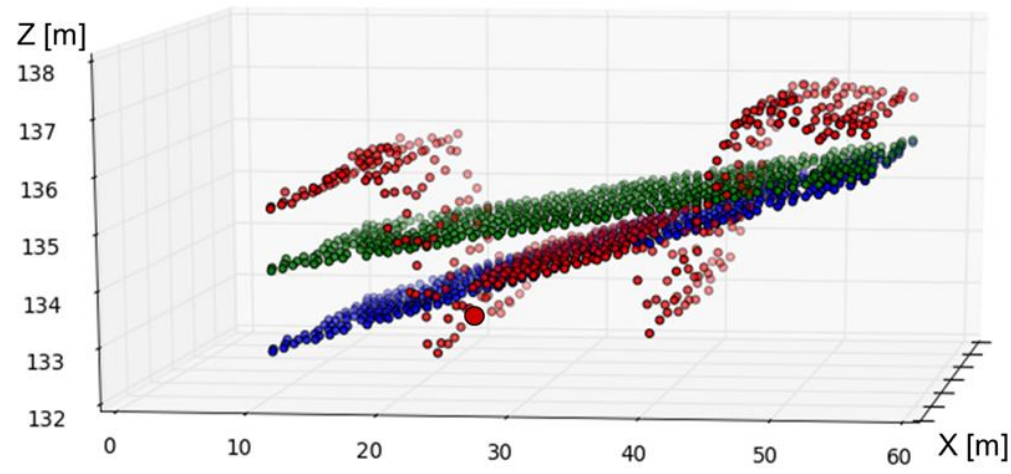

Points representing lane from ALS scanning strip no.1

Points representing plane fitted by means of the least squares method

Points representing plane fitted by means of RANSAC method

Fig. 8. The plane fitted to the set of points from ALS scanning strip no. 1 (source: own study)

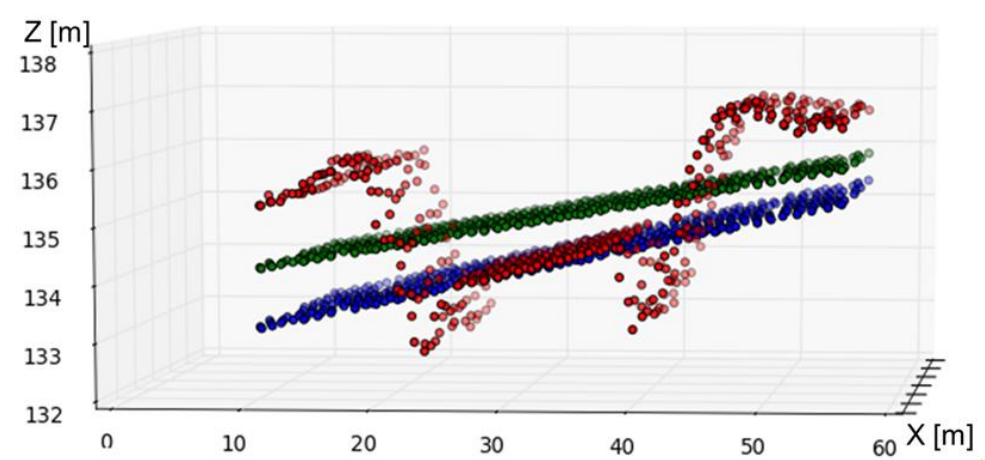

Points representing lane from ALS scanning strip no.2

Points representing plane fitted by means of the least squares method

Points representing plane fitted by means of RANSAC method

Fig. 9. The plane fitted to the set of points from ALS scanning strip no. 2 (source: own study) 

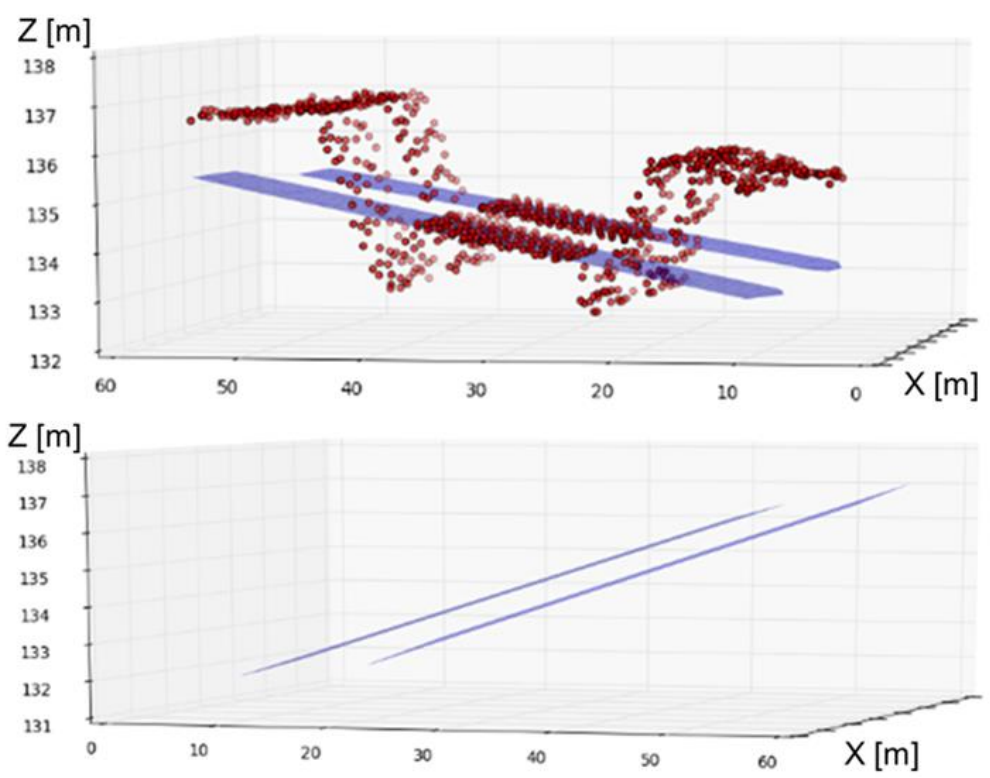

Fig. 10. The planes fitted into a set of points for the scanning strip no. 1 and scanning strip no. 2 (source: own study)

The method of RANSAC applied a plane equation. As it was already mentioned, this function has particular advantage of resistance of more than $80 \%$ to outliers. As it can be seen in Figure 9 and Fig. 10, data which were developed, represented the fragment of roadway (lane with the roadside ditches). The task was performed by fitting a plane into a lane in such way that the points belonging to the roadside ditches and embankments were not taken into account. For comparison, in Fig. 8 and Fig. 9 the results of fitting the plane by means of the least squares method is also presented. The authors wanted that the plane covered only the lane.

The tolerance range of $0,02 \mathrm{~m}$ was used, while the number of iteration was 20 . In the Fig. 10 the two planes fitted into scanning strips no. 1 and no. 2 by means of RANSAC method is shown.

By using the proposed method two surfaces were achieved. Then four lines perpendicular to these surfaces were established and in this way four points for each plane were selected. The distances between these points were calculated, and the mean value of these distances were taken as the value of the offset planes, and thus the offset between the ALS scanning strips (offset values). This value was $35 \mathrm{~cm}$. 


\section{CONCLUSIONS}

Airborne laser scanning provides large data sets. Although the technology has been around for several years, there are still areas that require individual studies and solutions. There is not always the possibility of applying a universal solution, hence so many studies in the literature concerning the adjustment of ALS scanning strips can be found e.g.: [6], [13]. The method proposed in this work is one of the approaches to the subject. The RANSAC method has particular advantage in the form of resistance to a large number of outliers. Therefore it enables the search for the best possible solution. In addition, the parameters are selected individually for each case.

Examples presented in this paper confirmed the possibility of using the RANSAC method in the process of ALS scanning strips adjustment and from the work the following conclusions can be drawn:

1. The RANSAC method may be used for fitting the ALS scanning strips.

2. The roadway may be a linear object used in the process of fitting strips, especially in areas where it is not easy to extract linear elements.

3. Fitting of two planes into two sets of points representing roadway allows gave two planes spaced $35 \mathrm{~cm}$.

4. A calculation of shift range between the ALS scanning strips allows to obtain a single, complete set of ALS points.

\section{REFERENCES}

1. Borowiecki I., Michalik A.: Klasyfikacja chmury punktów lotniczego skaningu laserowego z zastosowaniem programów Tiltan Tlid, Terrascan VRMesh. Infrastruktura i Ekologia Terenów Wiejskich 1/III, 2012.

2. Borkowski A., Jóźków G.: Correctness evaluation of the flakes based filtering method of airborne laser scanning data. Archives of Photogrammetry, Cartography and Remote Sensing, Vol. 17a, ISBN 97883-920594-9-2, 2007.

3. Błaszczak-Bąk W, Janowski A., Kamiński W., Rapiński J.: Optimization algorithm and filtration using the adaptive TIN model at the stage of initial processing of the ALS point cloud. Canadian Journal of Remote Sensing., No. 37(6), pp. 583-589. DOI: 10.5589/m12-001, 2011.

4. Csanyi N., Toth C., Grejner-Brzezinska D., Ray J.: Improving LiDAR Data Accuracy Using LiDAR Specific Ground Targets. ASPRS Annual Conference, Baltimore, MD, March 7-11, CD-ROM, 2005. 
5. Crombaghs M.J.E., Brügelmann, de Min E. J.: On the adjustment of overlapping strips of laser altimeter height data. International Archives of Photogrammetry and Remote Sensing, 33(Part 3A): pp. 230-237, 2000.

6. Friess, P.: Toward a rigorous methodology for airborne laser mapping. In: International Calibration and Orientation Workshop - EuroCOW 2006.

7. Fuksa K.: Przyczyny btędów lotniczego skaningu laserowego $i$ sposoby podniesienia dokładności chmury punktów. Praca dyplomowa Wydział Geodezji Górniczej i Inżynierii Środowiska, Akademia Górniczo-Hutnicza w Krakowie. 2010.

8. Greiner-Brzezinska, D., Toth C., Paska E.: Airborne remote sensing supporting traffic flow estimates. Proc. of 3rd International Symposium on Mobile Mapping Technology, Kunming, C 29-31, 2004, CD-ROM. 2004.

9. Janicka J., Rapinski J.: Outliers Detection by Ransac Algorithm in the Transformation of $2 D$ Coordinate Frames. Boletim de Ciencias Geodesicas, Vol. 20, Iss. 3, pp. 610-625. 2014.

10. Kilian J., Haala N., Englich M.: Capture and evaluation of airborne laser scanning data. IAPRS XXXI 3, Vienna. 1996.

11. Fischler M., Bolles R.: Random sample consensus: A paradigm for model fitting applications to image analysis and automated cartography. Proc. Image Understanding Workshop, pp. 71-88. 1980.

12. Pfeifer N., 2008: Strip Adjustment and DSM Computation. International School on LiDAR Technology 2008 IIT Kanpur, India.

13. Ressl C., Mandlburger G., Pfeifer N.: Investigating adjustment of Airborne Laser Scanning strips without usage of GNSS/IMU trajectory data. ISPRS Archives -Volume XXXVIII-3/W8, pp.195-200. 2009.

14. Torr, P., Murray, D.: The development and comparison of robust methods for estimating the fundamental matrix. Int. J. Comput. Vision 24(3), 271300. 1997.

15. Vosselman G.: Strip offset estimation using linear features. $3^{\text {rd }}$ International Workshop on Mapping Geo-Surfical Processes using Laser Altimetry, Columbs, Ohio, USA: 9. 2002.

16. Vosselman G., Maas H.G.: Adjustment and Filtering of Raw Laser Altimetry Data. Proceedings of OEEPE workshop on airborne laserscanning and interferometric SAR for detailed digital elevation models 1-3 March 2001, paper 5 (11 pages). Royal Institute of Technology Department of Geodesy and Photogrammetry 100 Stockholm, Sweden. 2001. 


\section{WYKORZYSTANIE ALGORYTMU RANSAC PRZY WPASOWANIU SZEREGÓW ALS}

\section{Streszczenie}

Podczas opracowywania danych pozyskanych w wyniku lotniczego skaningu laserowego istotną kwestią jest wpasowanie i nadanie georeferencji szeregom ALS w oparciu o powierzchnie wiążące oraz płaszczyzny referencyjne. Proces wyrównania szeregów polega na wzajemnym wpasowaniu szeregów oraz ich dopasowaniu do płaszczyzn referencyjnych. W jednoczesnym procesie wyrównawczym wiąże się wszystkie szeregi w jeden spójny geometrycznie blok, któremu nadaje się współrzędne terenowe. W procesie wyznaczania rozbieżności szeregów istotne jest określenie prawidłowej wielkości przesunięć (offsetów). Autorzy proponują w tym celu wykorzystanie algorytmu RANSAC.

Słowa kluczowe: lotniczy skaning laserowy, algorytm RANSAC, wpasowanie.

Editor received the manuscript: 08.09.2016 
PUSTA 